position has the best chance of succeeding. For this high position means energy under another form. It means that at some remote period a vast amount of personal energy was expended in raising the family into this high position. The founder of the family had, doubtless, greater energy than most of his fellows, and spent it in raising himself and his family into a position of advantage. The personal element may have long since disappeared from the family, but not before it had been transmuted into something else, in virtue of which the present representative is able to accomplish a great deal, owing solely to the high position which he has acquired through the efforts of another. We thus see that in the social world we have what may justly be termed two kinds of energy, namely :-

1. Aatual or personal energy.

2. Energy derived from position.

Let us now again turn to the physical world. In this, as in the social world, it is difficult to ascend. The force of gravity may be compared to that force which keeps a man down in the world. If a stone be shot upwards with great velocity, it may be said to have in it a great deal of actual energy, because it has the power of doing useful work or of overcoming up to a great height the obstacle interposed by gravity to its ascent, just as a man of great energy has the power of overcoming obstacles. But this stone as it continues to mount upwards will do so with a gradually decreasing velocity, until at the summit of its flight all the actual energy with which it started will have been spent in raising it against the force of gravity to this elevated position. It is now moving with no velocity-just, in fact, beginning to turn-and we may suppose it to be caught and lodged upon the top of a house. Here, then, it remains at rest, without the slightest tendency to motion of any lind, and we are led to ask what has become of the energy with which it began its flight? Has this energy disappeared from the universe without leaving behind it any equivalent? Is it lost for ever, and utterly wasted? But the answer to this question must be reserved for another article.

BALFOUR STEWART

\section{LEGISLATION AND NATURE}

$H E$ effect of Legislation upon Nature is one of those far-reaching subjects which men are only just beginning to investigate in a practical spirit. It is, of course, only a minor branch of the larger question of man's influence upon all external life and forms, but it has its special attractions, nevertheless, and may be pursued to advantage as an independent study. Incidentally, it illustrates many other problems. The diminutiveness of the Hindu cow, for example, may be due as much to the legislation which has made the domesticated animal sacred as to the nature of the climate of Hindustan. It is quite possible the oxen of this country would not have exhibited such a variety of forms and sizes had we selected one species and made it sacred some two or three thousand years ago. Take, again, the subject of maritime canals, which is now in its infancy. The Suez Canal has not existed long enough to have had any appreciable effect, either in modifying the coast-lines of the Mediterranean, or in creating any interchange of marine species; but it is likely enough to be one of a series, and we cannot predict what may be their effects. The diversion of the Nile may prove a serious matter, and now the Darien scheme has revived, a great impetus has been given to speculation, so that an ingenious projector has actually sketched a canal which should unite the Bristol Channel with the English Channel. Two more illustrations may suffice to make my meaning clear. There seems little apparent connection between woods and national greatness, but, nevertheless, the relation is a real one. When Spain lost the empire of the seas, she lost it from two causes-impoverished finances, due to a speculative trade in precious metals, and want of woods to build her ships. Her people had a foolish prejudice against trees, and an arid climate and reduced shipbuilding were the results. From Danzig to Pillau once stretched a thick pine forest. When King Frederic William I. was in want of money, one Herr Von Korff recommended its destruction. The experiment was a financial success, but the State was injured by it. As Willibald Alexis states, "the sea-winds rushed over the bared hills; the Frische Haff is half choked with sand ; the channel between Elbing, the sea, and Königsberg is endangered; and the fisheries in the Haff injured. The operation of Herr Von Korff brought the King 200,000 thalers. The State would now willingiy expend millions to restore the forests again."

Neither directly nor indirectly, in fact, can we touch nature by our laws, without beginning a new chain of causes, the end of which we cannot foresee. The consequences of human volition are always a little wonderful. When the treasures of Thorwaldsen were packed up in Rome, it was not dreamed that new plants would be conveyed to Copenhagen in the grasses of the Campagna, any more than Clusius, the first European writer who mentions the potato, could possibly foresee that half the miseries of Ireland would spring from its exclusive cultivation. What we owe to our game-laws, again, is a boundless subject which might be investigated by a naturalist with profit.

My inmediate purpose, however, is--strange as it may seem-with Mr. Lowe and his Budget. He deserves to be styled a real friend to the farmer, though apparently he has only given him a restricted use of germinating barley. Readers of Darwin will remember how he traces the connection between the num. ber of cats in a given locality, and the number of humble bees, and the abundance of red clover and heartsease. Well, Mr. Lowe's Budget starts a similar House-that-Jackbuilt. The freedom of firearms from taxation affects their number in any district, the number of guns determines the number of our small birds, and the number of our small birds affects the immunity of our fields from gxasshoppers, cricket-moles, beetles, locusts, slugs, \&c. Mr. Lowe was concerned for the security of life, for the prevention of early quasi-poaching habits, but his $\mathrm{I} l$. tax may effect a revolution all the same. It is no longer a secret, that wherever a persistent warfare is carried on against small birds-against martins, blackbirds, sparrows, larks, \&c.-vegetable life is sure to suffer. In the Isle of Bourbon, as M. Michelet tells us, the martin was exterminated, and a plague of grasshoppers followed; in Hungary, the sparrow was proscribed, until this valiant militia of the fields had to be recalled; in the neighbourhood 
of Rouen, the blackbird was shot down without mercy, and many a meadow's turf could be roiled up like a carpet; and in this country we had, until lately, our sparrow clubs, which paid for little victims at so many a dozen, just as two or three hundred years ago some of our pious churchwardens used to purchase hedgehogs of truant schoolboys in the rural districts, a lamentable increase of pestiferous insects being the consequence. The Rev. Charles Kingsley gives us a more recent example. In Trinidad, the free negro has been banging away at the small birds, partly for his own pleasure, and partly to supply the London markets and our laclies' hats. What has been the consequence? "Already the turf of the savannah, or public park, close by, is being destroyed by hordes of mole-crickets, almost exactly like (strange to say) those of our old English meadows; and unless something is done to save the birds, the canes and other crops will surely suffer in their turn. A gun-licence would be, it seems, both umpopular and easily evaded in a wild forest country. A heavy export tax on bird-skins has been preferred" (Good Words, April). A single pair of swallows, says M. Michelet, carry every week to the nest 4,300 caterpillars or coleoptera. The blackbird is a notorious insect-eater, and consumes hundreds of imperfect insects every day, to say nothing of worms and slugs. The common sparrow is a vivacious feeder, and somewhat dainty withal, but it makes great havoc with young worms and soft insects. All our field birds, in short, troublesome and non-melodious as many of them are, rid us of millions of fast breeding insects which would otherwise do incalculable injury to our vegetation, and could not well be destroyed by artificial means. Indeed, we disturb a natural arrangement when we step in and decimate a predatory class without also destroying their victims, and therefore it is gratifying to find $\mathrm{Mr}$. Lowe putting a check upon amateur sportsmen, who bang away, reckless of consequences either to themselves or others. A little time ago we agreed to protect our sea-birds, because we found they showed us "schooling" fish, and warned our seamen from dangerous rocks in misty weather. This time our legislation is less direct. We have not had a select committee on the sparrow-there are plenty of chatterers in the House of Commons who might be "sat upon" to advantage; we have not even anticipated a Ministry of Agriculture by investigating the sources of injury to growing crops; but we have been moved by social advantages, and the bright-eyed broods of field and wood will profit by our sense of security and our desire to equalise taxation.

A word on another topic. The rating of woods and plantations is threatened. It is part of the very question I have so hastily touched upon. Wherever farms are very bare of trees, insects always abound. The locust and the grasshopper delight in the plain, whilst the smaller insects thrive in the young woods that give shelter to their enemies. If we do anything to diminish the planting of trees, we shall increase our insects and also dry our already impoverished soils. We are protecting salmonwhy should we not protect our woods, and with them our birds and our crops? Dean Stanley notes that Jewish tradition ascribes to Joshua certain useful regulations as to woods-the grazing of cattle therein, the cutting of sticks, and the preserving of thinly-planted trees. There was wisdom in them all. Watch a bare and a wooded hill on a cloudy day, or a well-wooded farm in a dry summer, and you will see a difference which need not be described. Disafforesting threatens to become as common in the nineteenth as enclosuring was in the sixteenth century. Are we wise to hasten it?

\section{E. GOADBY.}

\section{DR. FELINECK ON METEOROLOGICAL OBSERVATIONS}

Anleitung zur Anstellung meteorologischer Beobachtungen und Sammlung vor Hilfstafeln. Dr. Carl Jelineck. Royal 8vo, pp. 193, with 17 figures. (Vienna, 1869. London: Williams and Norgate, price $6 s$.)

A COMPARISON between the instructions of M. Carl Kreil, the late director of the Austrian Central Office for Meteorology and Terrestrial Magnetism, and those now issued by his successor, demonstrates steady and sound progress in practical meteorology. M. Kreil had to sow his seed on uncultivated soil, and was only partially supplied with the more modern implements of cultivation; Dr. Jelineck, on the contrary, has had before him the successive results of nearly a quarter of a century, and has profited by the vast experience gained from the correspondence carried on during that time between the central office and the numerous stations, distributed over the wide geographical area of the Austrian empire with its striking physical contrasts. No wonder then, that Dr. Jelineck's work, which the author modestly calls "a guide to meteorological observations, with particular reference to the stations in Austria and Hungary," has developed, under his hands, into an excellent manual of practical meteorology, which will prove, in many respects, most valuable to the observers of every country. In the instructions of his predecessor such important subjects as the employment of the aneroid and marine barometers, and of the maximum and minimum thermometers, are not discussed at all, and little attention is paid to a rigid reduction of the observations.

The introductory part of the present work treats on the following subjects : general organisation of the system of meteorological observations in Austria and Hungary; conditions for establishing new stations; regulations for the official correspondence throtgh the post and telegraph offices; local requirements and instrumental equipment of stations, with a precise statement of the necessary expenditure; a list of the most recent and important works on meteorology published in Germany, England, and France; hours of observation and means for determining the true local mean time.

Then follows a concise and clear description illustrated by excellent figures, of the different kinds of barometers and aneroids, a discussion of their relative advantages and defects, and an exposition of the principal formulæ used in the reductions of the observations, with wellselected examples fully worked out, for those observers whose mathematical knowledge is deficient. It appears that the form of barometer mostly in use at the Austrian stations, is that in which there is no provision for adjusting the zero of the scale to the fluctuating surface of the mercury in the cistern. Hence, only one displacement of the index is made for every observation, viz. that at the upper surface of the mercurial column. This is undoubt- 